\title{
A CESSÃO de CRÉDITOS: REFLEXÕES SOBRE A CAUSALIDADE NA TRANSMISSÃO DE BENS NO DIREITO BRASILEIRO
}

\author{
Rodrigo Xavier Leonardo*
}

RESUMO: Inicia-se ente ensaio por uma reflexão do direito das obrigações em sua estrutura e função, perspectivado a partir da lógica formal e do direito natural e, posteriormente, por uma crítica às concepções tradicionais do direito das obrigações. Aproxima-se, a partir de então, do tema por intermédio de uma reflexão sobre o discurso histórico e a cessão de créditos, objetivando demonstrar como a transmissibilidade de créditos, nalguma medida, projeta escolhas fundamentais do direito das obrigações. Neste diapasão, a seguir, analisa-se o crédito como valor para compreender as justificativas de sua transmissibilidade nos tempos modernos. Por fim, procura-se analisar a cessão de créditos no direito brasileiro, investigando sua natureza jurídica e, sobretudo, questionando sobre a sua abstratividade ou causalidade.

\section{INTRODUÇÃO}

O direito das obrigações até não muito tempo atrás era identificado como um ramo do direito privado cujas estruturas e funções seriam um tanto quanto estáticas em face da dinâmica da economia.

Este prejulgamento da disciplina foi apontado por vários pensadores modernos do direito. Giorgi Giorgi, para representar esta linha de reflexão, utiliza-se de Bélime

* Professor Substituto do Departamento de Direito Civil e Processual Civil da UFPR. Bacharel em Direito pela UFPR. Mestre e Doutorando em Direito pela USP. Advogado. que, em sua Filosofia do direito, escreveu que "elles sont demeurées (les obligations) comme des colomnes inébranlables de jurisprudence, autor de queles se railient tout les principes". ${ }^{1}$

Eugène Gaudemet evidencia essa impressão de imutabilidade ou, pelo menos, de estabilidade preponderante das relações jurídicas obrigacionais, pela assimetria entre o direito das obrigações e o meio social, quando o regramento correspondente é

1 BÉLIME. Philosophie du droit. V.IV. Apud GIORGI, J. Teoría de las obligaciones en el derecho moderno. v.VI. Madrid: Hijos de Reus, 1911, p.71. 
comparado com o direito das coisas e o direito de família. ${ }^{2}$

$\mathrm{O}$ direito das coisas seria intimamente vinculado à organização política e social de cada sociedade; o direito de família, por sua vez, estaria vinculado diretamente aos aspectos mais íntimos da constituição moral de uma nação e, por essa razão, passaria quase imediatamente a refletir as mudanças de cada tempo, em cada lugar.

O direito das obrigações, todavia, permaneceria cristalizado pela lógica formal e por princípios da justiça natural, pois, na expressão de Gaudemet: "Quelle influence des conceptions de cet ordre pourraient elles avoir sur les droits d'un vendeur, créancier du prix?". ${ }^{3}$ Isto ressaltaria, ainda, na aparente maior facilidade dos processos de unificação dos princípios do direito das obrigações, aproximadamente proposto pelo Unidroit, dentre outros projetos em andamento, direcionados à uniformização e até mesmo à unificação dos contratos.

É importante destacar, no entanto, que Giorgi e Gaudemet, autores do século XX, a despeito de reconhecer esse prejulgamento quanto a uma imutabilidade do direito das obrigações, não poupam críticas a essa leitura da realidade. ${ }^{4}$ Estariam eles certos?

${ }^{2}$ GAUDEMET, É. Théorie genérale des obligations. Paris: Sirey, 1965, p.10.

3 GAUDEMET, Théorie genérale des obligations, p. 10 .

${ }^{4}$ Para Gaudemet “(...) si le droit des obligations est moins intimement lié que les autres à l'évolution politique et morale, il est intimement lié à une autre évolution, politique et morale, il est intimement lié à une autre évolution, plus lente, mais tout aussi réelle, et singulièrement accélérée depuis un siècle, l'evolution commerciale ou, plus généralement, l'évolution économique" (GAUDEMET, Théorie genérale des
Ao refletirmos sobre a cessão de crédito e a assunção de dívida - considerados como os principais fenômenos concernentes à transmissibilidades nas obrigações -, podemos realmente encontrar muito mais do que uma simples técnica para circulação do crédito. Podemos encontrar um autêntico mecanismo para geração de riquezas. E aqui, talvez, seja possível confrontar a tese da imutabilidade do direito das obrigações mediante uma investigação de um dos seus principais institutos: a cessão de créditos.

Depara-se, neste tema, com um dos mais antigos conflitos entre o conceitualismo jurídico e as exigências da realidade. Por essa razão, por intermédio dessa parte do direito das obrigações, pode-se refletir sobre o todo da disciplina e, porque não dizer, do próprio direito privado.

\section{O DISCURSO HISTÓRICO E A REFLEXÃO SOBRE A CESSÃO DE CRÉDITOS}

O tema da transmissibilidade nas obrigações encontra-se de tal maneira vinculado à noção jurídica de obrigação que

obligations, p.10). Giorgi, a seu tempo, identifica no tema da transmissibilidade nas posições jurídicas obrigacionais um sinal de falsidade do prejulgamento quanto a imutabilidade neste ramo do direito privado: “(...) cuando Bélime ensalzaba la inmutabilidad de la teoría de las obligaciones, no pensaba, seguramente, en el maravilloso desenvolvimiento que, con lento pero incesante progreso, ha sufrido la transmisión de los créditos, ni en la enorme distancia que lo mismo en el orden teórico que en el práctico separa las antiguas y poco expeditas formas de transmisión de la sencilla y expedita transmisión de los títulos á la orden y al portador, las manifestaciones más útiles del genio económico en el campo de las obligaciones (GIORGI, J. Teoría de las obligaciones en el derecho moderno. v.VI. Madrid: Hijos de Reus, 1911, p.71). 
se mostra difícil traçar os correspondentes lineamentos históricos pertinentes a um sem falar do outro.

Para evitar adentrar à fatigosa discussão sobre a noção jurídica de obrigação, ${ }^{5}$ propõe-se partir de seu elemento mais reluzente: o vínculo jurídico.

A própria palavra "obrigação" conduziria à idéia de vínculo. Obrigação, atenta Josserand, ${ }^{6}$ provém do latim $o b+$ ligatio. Daí o elemento vínculo ser eternizado na clássica definição encontrada nas Instituições de Justiniano: “obligatio est juris vinculum, quo necessitate adstringimur alicujus solvendae rei".

Há unissonância entre os autores romanistas, partindo das fontes que lhe são acessíveis, que em direito romano essa ligação ou vínculo caracterizava-se por ser personalíssimo, inexistindo um mecanismo de direito material para a sucessão singular de créditos e de dívidas. ${ }^{7}$ A pessoa do credor e a pessoa do

5 Procuramos desenvolver considerações sobre este tema noutra oportunidade, LEONARDO, R. X. Direito das obrigações: em busca de elementos caracterizadores para compreensão do livro I da parte especial do Código Civil.In: CANEZIN, C. C. (Org.). Arte jurídica: Biblioteca científica do programa de pós-graduação em Direito Civil e Processo Civil da Universidade Estadual de Londrina. v.I. Curitiba: Juruá, 2005, p.277.

6 JOSSERAND, L. Cours de droit civil positif français. v.II. 12.ed. Pais: Sirey, 1933, p.2.

${ }^{7}$ Para Guido Astuti: "Il principio romano della intransmissibilità delle obbligazioni si ricollega alla struttura tipica dell'actio in personam, e alla concezione originaria dell'obligatio, come vincolo essenzialmente personale, caratterizzato dalla costrizione giuridica soggettiva del debitore per l'adempimento della prestazione, configurato come atto volontario e direttamente incoercibile: ne consegue che, pur dopo l'introduzione della responsabilità e soddisfazione patrimoniale, e la devedor eram essenciais para a manutenção do vínculo obrigacional, ${ }^{8}$ de modo que qualquer alteração desse elemento pessoal, seja no pólo ativo, seja no pólo passivo, na relação jurídica, implicaria a alteração da própria relação jurídica. ${ }^{9}$

Mas por qual razão o Direito Romano tão afeito às soluções práticas ao invés do conceitualismo -, teria negado tão veementemente as vantagens negociais decorrentes da circulação de créditos e de dívidas?

Para além da simples explicação do fenômeno pelos efeitos dele decorrentes e sem descuidar dalgumas precauções metodológicas para a reflexão crítica por intermédio do discurso da história do

conseguente transformazione dell'obligatio ancora nel pensiero della giurisprudenza classica i soggetti del rapporto obbligatorio sono immutabili, e di regola i diritti di credito non sono transferibili da persona a persona, a titolo particolare" (ASTUTI, G. Cessione (storia). In: Enciclopedia del diritto. t.VI. Milano: Giuffrè, ano, p.806). Max Kaser, por sua vez, explica que: "a transmissão do crédito por uma pessoa a outra (subsistindo a obrigação) não era permitida aos Romanos por mudança de credor, porque em Roma os direitos (subjectivos), ao menos os derivados de um crédito, estavam vinculados ao seu titular e não eram transmissíveis a outrem por sucessão individual" (KASER, M. Direito privado romano. Lisboa: Calouste Gulbekian, 1999, p.304).

${ }^{8}$ Para Tobeñas, "se pensaba que es de interés para el acreedor tener un deudor más solvente y honrado que otro, y no es indiferente al deudor tener un acreedor más compasivo, menos riguroso que otro" (TOBEÑAS, J. C. Derecho civil español, común y foral. 8.ed. t.III. Madrid: Editorial Reus, 1954, p.234).

${ }^{9}$ GIORGI, J. Teoría de las obligaciones en el derecho moderno. v.VI. Madrid: Hijos de Reus, 1911 , p.71. 
direito, ${ }^{10}$ enumeram-se algumas razões para esse personalismo obrigacional. Em primeiro lugar, as próprias origens mais primitivas do vínculo obrigacional seriam mágicoreligiosas, justificando-se o vínculo entre pessoas por uma concepção mística, tal como a idéia de punição divina contra aqueles que não respeitassem os efeitos próprios aos ritos de ligação verbalizados sob os olhos da divindade protetora e castigadora. ${ }^{11}$

${ }^{10}$ Parte-se, aqui, da advertência metodológia de Ricardo Marcelo Fonseca que critica a re-construção dos institutos de direito privado pela história do direito mediante uma seqüência linear: "De fato, o estudo linear da história (e de modo particular da história do direito), que amontoa tudo o que já passou numa superposição harmônica e coerente de institutos jurídicos através do tempo, acaba impondo uma lógica ao passado que em verdade lhe é estranha, ao mesmo tempo em que lança sobre a época pretérita as questões, preocupações, valorações e ansiedades que pertencem ao presente (e ao cientista que produz tal tipo de conhecimento)" (FONSECA, R. M. Modernidade e contrato de trabalho: do sujeito de direito à sujeição jurídica. São Paulo: Editora LTr, 2002, p.26). Neste sentido, também Sérgio Said Staut critica o historicismo no direito: "Essa maneira 'tradicional' e 'positivista' de entender o passado e a História do Direito, chamada de historiciosmo, causam geralmente duas graves distorções (...) o passado é utilizado simplesmente para justificar o presente. É a lógica do presente que preside e se apropria de toda a investigação do passado; são estabelecidas conexões diretas entre presente e passado que não permitem visualizar as suas descontinuidades" (STAUT, S. S. Algumas precauções metodológicas para o estudo do direito civil. Arte jurídica: Biblioteca científica do programa de pósgraduação em Direito Civil e Processo Civil da Universidade Estadual de Londrina. v.I. Curitiba: Juruá, 2005, p.306).

11 "L'une met en avant des considérations magico-religieuses, qui auraient joué un grand rôle dans une société encore <primitive $>$ où régneraient la violence et la peur. C'est ainsi que P. Huvelin suggérait, pour expliquer l'origine d l'obligation, une première phase magico-religieuse. Un procédé
A explicação parece encontrar fundamentos antropológicos numa lógica de reciprocidade verificável, segundo Rodolfo Sacco, nas sociedades mais primitivas. ${ }^{12}$

Em direito romano, a noção de vínculo implicava atamento material da pessoa do devedor, que poderia sofrer a execução pessoal, mediante a sujeição à escravidão ou até a própria morte, nos casos de descumprimento. ${ }^{13}$ Por essa razão, do lado passivo, não parecia possível substituir a pessoa do devedor, permitindo-se que uma

mystérieux d'assujettissement serait d'abbord apparu. Ce qu'il était, on l'ignore. Puis serait intervenue l'idée d'une vengeance divine contre celui qui ne respectait pas son engagement. Ici encore les formes de cette vengeance, ses manifestations restent dans l'obscurité. Finalement, on serait passé du lien magico-religieux au lien juridique" (GAUDEMET, J. Naissance d'une notion juridique. Les débuts de l' <obligation> dans le droit de la Rome antique. In: Archives de philosophie du droit: L'Obbligation. Paris: Dalloz, 2000, p.27).

12 "L'home sacrifie au Dieu, Dieu assure sa protection à l'homme. Le survivant rend le culte au mort, le mort donne son assistance au survivant. L' agriculteur exécute ses prestations en faveur de la terre, celle-ci lui donnera ses fruits. Dans les sociétés africaines subsahariennes traditionnelles, la prestation tributaire est spontanée, mais elle se croise avec l'attribution de terres faite par le chef. L'analyse anthropologique nous fait voir une réciprocité semblable dans la vengeance et jusque dans la guerre" (SACCO, R. À la recherche de l'origine de l'obligation. In: Archives de philosophie du droit: L'Obbligation. Paris: Dalloz, 2000, p.36).

13 "Según el derecho antiguo el deudor respondía del cumplimiento de sus obligaciones en primer lugar con su persona, aunque no fuera exclusivamente. Si no podía satisfacer al acreedor la cantidad por la que hubiera sido condenado y no se le eximía de la obligación de pagar, su suerte era el ser vendido como esclavo, y quizá la muerte, que podía darle el acreedor" (JÖRS, P.; KUNKEL, W. Derecho privado romano. Trad. L. Pietro Castro. Barcelona: Labor, 1937, p.329). 
terceira pessoa, alheia à relação, ficasse afinal exposta a tão graves males no caso de descumprimento; tampouco se mostrava conveniente a facilidade na substituição do credor, que poderia resultar na troca de uma pessoa mais clemente por outra mais rigorosa.

Ademais, conforme explicação de Menezes Leitão, o formalismo na constituição das obrigações resultava na necessidade da repetição de fórmulas rituais solenes préfixadas para qualquer alteração subjetiva na relação obrigacional. ${ }^{14}$

Sob essas circunstâncias, duas soluções surgiram para se alcançar o efeito prático da transmissão de créditos e de dívidas em direito romano: em primeiro lugar a novação e, posteriormente, a transposição processual mediante mandatum in rem suam ${ }^{15}$

Ambas apresentavam muitos inconvenientes. A novação, por intermédio da extinção da relação jurídico-obrigacional originária pela constituição de uma nova, conduzia a uma desfavorável e inevitável extinção das garantias, sem contar a limitação prática concernente à exigência do consentimento da contraparte que, invariavelmente, poderia "negociar", em benefício próprio e exclusivo, essa aceitação. ${ }^{16}$

$\mathrm{O}$ mandatum in rem suam surge como uma solução processual adaptada ao processo formular. $\mathrm{O}$ titular do crédito outorgava a um terceiro poderes de representação em causa própria para, mediante o exercício de

${ }^{14}$ MENEZES LEITÃO, L. M. T. Cessão de créditos. Coimbra: Almedina, 2005, p.25.

15 PONTES DE MIRANDA. Tratado de Direito Privado. t.XXIII. Rio de Janeiro: Borsoi, 1958, p.248.

16 MENEZES LEITÃO, Cessão de créditos, p.26. uma actio, este pudesse acionar o crédito, satisfazendo-se com o produto da cobrança. ${ }^{17}$

A solução também comportava graves incovenientes, pois, pelo menos até a conclusão da litis contestatio, o outorgante tinha possibilidade de revogar o mandato e, credor que era, podia até mesmo extinguir o crédito transigir ou remitir a dívida, tudo isso sem contar com a possibilidade de buscar a condenação do devedor. Se o outorgante falecia, por sua vez, ou se falecia o outorgado, extinguia-se o mandato. ${ }^{18}$

Para superar estas limitações, entre o período clássico e pós-clássico do direito romano, conferiu-se ao outorgado a chamada

17 Astuti esclarece que "Secondo le norme della procedura formulare, il cessionario-mandatario agiva alieno nomine, assumendo l'intentio dalla persona del titolare del diritto, e chiedendo la condemnatio a proprio favore (Gai. 4, 86 ) (ASTUTI, Cessione (storia), p.807. Menezes Leitão, por sua vez, explica que "No direito romano, a solicitação de representação processual como cognitor ou procurator tinha natureza abstracta, ainda que a ela estivesse naturalmente subjacente uma relação de mandato. O cedente poderia assim, para efeitos da cobrança do crédito, transmitir ao cessionários os meios processuais que lhe cabiam contra o devedor, sob a forma de uma actio mandata, referindo os romanos que neste caso o credor praestabat, mandabat ou cedebat actionem ao seu substituto. Este esquema permitia ao cedente (como mandante) encarregar o cessionário (como mandatário) de cobrar o crédito pessoalmente (mandatum ad agendum), caso em que este intentartia a acção nomine alieno, assumindo a intentio do cedente, mas obteria uma condenação a seu próprio favor, enquanto representante processual. Nesse caso, normalmente o cedente teria contra o cessionário, enquanto seu mandatário, uma actio mandati para obter a entrega do valor da cobrança. No entanto, o cedente perderia essa acção, caso autorizasse o mandatário a guardar para si o resultado da cobrança (mandatum in rem suam)" (MENEZES LEITÃo, Cessão de créditos, p.26-27).

18 PONTES DE MIRANDA, Tratado de Direito Privado. t.XXIII, p.248. 
actio utilis ${ }^{19}$ para que esse pudesse acionar o crédito em nome próprio.

Mantinha-se, todavia, uma fragilidade: o credor originário não perdia a ação direta para satisfação do mesmo crédito.

Esta possibilidade foi afastada apenas quando se admitiu a denuntiatio do devedor, mediante a qual este deixaria de obter a liberação na hipótese de pagamento ao credor originário (cedente). ${ }^{20}$ É interessante notar

19 Guido Astuti elucida que "Un ulteriore e decisivo passo vene compiuto col riconoscimento di un'actio utilis al cessionario, che in tal guisa fu legittimato ad agire non più come mandatario del cedente, ma a nome proprio: così finalmente la cessione poté acquistare efficacia diretta ed autonoma fisionomia, sottraendo l'qacquirente di un credito all'incertezza che prima gli derivava dalla posizione di procuratos in rem suam. È controverso entro quali limiti questo rimedio sia stato attuato nell'età classica" (ASTUTI, Cessione (storia), p.807).

${ }^{20}$ MENEZES LEITÃo, Cessão de créditos, p.30. Explica Pontes de Miranda que: “ (...) o outorgado podia impedir que o devedor pagasse, com eficácia liberatória, ao outorgante, desde que houvesse a denuntiatio do que se passou. Chegou-se quase à concepção da cessão de crédito, que é construção do direito comum. A 'notificação' segundo o art. 1.069 do Código Civil tem raízes na denuntiatio dos textos de Alexandre Severo e de Gordiano, mas a eficácia, hoje, é eficácia da cessão, estendida ao terceiro; no direito romano pós-clássico, apenas era eficácia do mandato em causa própria, ou do exercício da ação útil" (PONTES DE MIRANDA, Tratado de Direito Privado. t.XXIII., p.249). Para alguns autores, com a actio utilis, teria ocorrido uma verdadeira aceitação indireta da cessão de crédito. Nesse sentido, cf. GIORGI, Teoría de las obligaciones en el derecho moderno, p.73). Segundo Astuti, no direito justinianeo, com a introdução da actio utilis "l'istituto acquista una fisionomia nuova: mentre nel diritto classico è ignorato il transferimento delle obbligazioni, e il cessionario acquista solo la facoltà di esercitare un credito altrui, nel diritto giustianeo l'antico principio è sostanzialmente travolto, e sostituito da quello della transferibilità dei crediti. Non sembra esatto dire che l'obbligazione sussiste nei confronti del creditore originario, mentre il cessionario acquista solo un'azione contro il debitore, que, segundo Biondo Biondi, se por um lado a actio utilis afastou a operação de cessão da figura da representação, por outros, foram criados para ela uma série de outras restrições visando proibir especulações ilícitas por intermédio da cessão. ${ }^{21}$

A transmissibilidade das obrigações tomou diferentes caminhos no direito bizantino e no direito romano vulgar do Ocidente. Enquanto no primeiro, com a extinção do conceito de actio utilis, mediante a simples denuntiatio já se operaria a cessão de crédito, ${ }^{22}$ na parte

né che l'actio utilis contine (come già sostienne l'Eisele), una finta delegazione: nel sistema giustinianeo non v'é ormai difficoltà ad ammettere $<$ che perduri una obbligazione nonostante lo scambio dei soggetti, in forza di successione a titolo singolare> (Ferrini)" (ASTUTI, Cessione (storia), p.808). Em sentido contrário, Pontes de Miranda assevera que: "A ação não era a do outorgante, que se transferisse. Era ação atribuída ao outorgado, em lugar do objeto da obrigação; e não por transferência da obrigação, ou do débito. Às vezes os textos parecem permitir que até aí se vá, mas em verdade só se trata de maneiras inexatas de expressão" (PONTES DE MIRANDA, Tratado de Direito Privado, t.XXIII, p.249).

${ }^{21}$ Nas palavras de Biondo Biondi: "Quando si generalizza il sistema dell'actio utilis e la cessione si stacca dalla rappresentanza, per ragioni politicosociali si vieta la cessione di taluni crediti o a favore di talune persone Costantino (CI. 8,36,2) e Giustiniano (CI. $2,13,2)$ vietano la cessione in potentiorem, cioè a persone di rango sociale più elevato e potenti, per escludere ogni possibile vessazione verso il debitore. Giustiniano (Nov. 75,5) proibisce la cessione al tutore dei crediti verso il pupillo" (BIONDI, Biondo, Diritto Romano, p.346).

22 Diz o autor: "Efectivamente, a sucessiva concessão das actiones utiles ao adquirente do crédito leva a que, após a extinção daquele conceito, a situação do cessionário pudesse ser vista como titular de um verdadeiro direito sobre o devedor, ocorrendo assim uma efectiva transmissão do crédito, de que a denuntiatio passa a ser considerada como um simples anúncio, que produzia que o devedor deixasse de ficar liberado com o pagamento do cedente" (MENEZES LEITÃo, Cessão de créditos, p.31). 
ocidental do Império, manteve-se a solução processual de transmissão mediante o mandato in rem suam, sem nem mesmo contar com a actio utilis.

Tampouco se verifica alguma sofisticação da transmissão de créditos no direito antigo dos povos germânicos. Pode-se dizer que, pelo contrário, até pelo menos o fim da Idade Média, a transmissão de crédito foi dificultada, voltando a prevalecer a idéia de intransmissibilidade. ${ }^{23}$

A escola dos glosadores e dos comentaristas ou pós-glosadores fixou-se nos traços de intransmissibilidade das obrigações em direito romano, surgindo neste período brocados como o de que os créditos aderem aos ossos (nomina ossibus inhaerent) comparando sua relação como a da lepra ao próprio corpo (ejus ossibus adhaeret ut lepra cuti). ${ }^{24}$

${ }^{23}$ Menezes Leitão sintetiza que "a posição que actualmente parece prevalecer é, no entanto, a de que o antigo Direito Germânico não admitiria a transmissão dos créditos, tendo esta apenas surgido no fim da Idade Média nos Direitos das cidades alemãs, como Magdeburg e Breslau, apresentando-se vários fundamentos para essa posição. Para Mitteis/ Lieberich, os créditos seriam vistos no antigo direito germânico como tendo fonte delitual, o que levava a que não pudessem ser transmitidos, já que apenas o lesado poderia reclamar do lesante a indemnização que à sua pessoa era devida (...) Apenas numa fase posterior, em que o crédito passou a ser reconhecido como elemento activo do patrimônio é que se passou a admitir a faculdade de o credor o transmitir, inicialmente com o consentimento do devedor, para depois no fim da Idade Média, os direitos das cidades passaram a reconhecer a transmissão, normalmente mediante o registro no livro da cidade" (MENEZES LEITÃO, Cessão de créditos, p.31).

${ }^{24}$ Nas palavras de Lacerda de Almeida: "a par da transformação do conceito fundamental da obrigação em Direito Romano, uma escravidão do devedor é á divida, divida tão ligada com elle, tão pessoal, tão inseparavel delle devedor, que chegaram
Neste período, todavia, adiciona-se mais um argumento à intransmissibilidade: $\mathrm{o}$ fato dos créditos não serem susceptíveis de posse, impossibilitando-se, por esta razão, a traditio, considerada como o negócio necessário para a transmissão de bens corpóreos. ${ }^{25}$

Os primeiros sinais de uma verdadeira transmissão de crédito surgem a partir do século XIII, em decorrência de construções do direito costumeiro francês e das concepções humanistas.

Ao que tudo indica, tomando por base a reflexão crítica de alguns historiadores do direito, a verdadeira alteração nessa matéria não se deu por intermédio de construções doutrinárias, mas pelas necessidades concretas advindas do desenvolvimento das trocas comerciais ao longo da expansão do império romano e mesmo após a sua cisão. ${ }^{26}$ Por mais que uma determinada concepção de obrigação personalíssima eventualmente

os medievaes a comparal-a á lepra adherente ao corpo do leproso e que se lhe não pode arrancar nem tirar sem o proprio corpo: ejus ossibus adhaeret ut lepra cuti" (LARCEDA DE ALMEIDA. Dos effeitos das obrigações. Rio de Janeiro: Freitas Bastos, 1934, p.361).

25 MENEZES LEITÃO, Cessão de créditos, p.47.

26 Neste sentido, Astuti, partindo de Ferrini, observa que a consagração da actio utilis tem origem em práticas comerciais anteriores a Justiniano: "Il Ferrini, pur rilevando queste alterazioni, ritenne tuttavia che esse confermassero una prassi preesistente, per cui l'actio utilis sarebbe stata accordata, già prima di Giustiniano, in alcune ipotesi di cessione di crediti" (ASTUTI, Cessione (storia), p.808). Max Kaser, por sua vez, aponta que mesmo no direito romano pós clássico, no período do dito 'direito romano vulgar', a matéria da cessão de créditos teria progredido: "Só muito esporadicamente a vulgarização alcançou progressos materiais (como na representação através de pessoas livres e na cessão de direitos de crédito)" (KASER, Direito Privado Romano, p.27). 
tivesse predominância e resistência (pelo menos até o século XIII!) isto não impedia que mecanismos de transmissão de crédito não fossem criados pelas necessidades práticas de cada época.

\section{O CRÉdITO COMO VALOR E SUA TRANSMISSIBILIDADE NOS TEMPOS MODERNOS}

A sustentação teórica para a cessão de créditos vem a se estabelecer com os pensadores jusnaturalistas que reconhecem no crédito um bem integrante do patrimônio do credor passível de circulação como as outras riquezas que ao seu lado figuram.

Menezes Leitão explica que

A doutrina jusnaturalista trouxe uma concepção diferente da cessão de créditos, na medida em que, ao representar a obrigação como uma alienação da liberdade do devedor em benefício do credor, veio simultaneamente qualificar o direito de crédito como um direito de domínio sobre uma acção de outrem. Esta concepção levou ao reconhecimento de que o direito de crédito constituiria, à semelhança da propriedade sobre coisas corpóreas, um elemento do patrimônio do credor, que poderia ser assim transmissível como qualquer outra componente patrimonial. ${ }^{27}$

A percepção do crédito como um elemento integrante do patrimônio do indivíduo promove o suporte necessário para a justificação da livre cedibilidade:

GROTIUS, apesar de, inspirado nas Institutas de GAIUS, classificar os direitos em direitos das pessoas (Livro I), direitos reais (Livro II) e direitos pessoais (Livro III), vem admitir que os direitos reais possam ter por objecto coisas incorpóreas, as quais define como as que

${ }^{27}$ MENEZES LEITÃO, Cessão de créditos, p.129. consistem em direitos. Entre esses direitos incluir-se-ia o direito de crédito, estabelecendo GROTIUS uma distinção entre o direito sobre a coisa (beheering, jus in re) e o direito à coisa (inschuld, jus ad rem) que identifica com o direito de crédito (...) Assim, GROTIUS, prevê expressamente que as res incorporales podem ser objecto de compra e venda, fazendo referência expressa à venda de direitos de crédito, mas não a solvência do devedor. ${ }^{28}$

O posicionamento do crédito como um elemento do patrimônio importou numa aproximação entre crédito e propriedade enquanto bens passíveis de livre disposição. O fato dessa recomposição conceitual ocorrer no pensamento jusracionalista não é aleatório. Trata-se de mais um sinal da cisão entre pessoas e bens, tal como observou José Antônio Peres Gediel, com a ampliação da noção de bens para além daquilo que é material: "Segundo já preconizava o jusracionalismo cristão, no final da Idade Média, o homem, por sua descendência divina, gozava de autonomia terrena e respondia, individualmente, perante o Criador, não se confundindo, assim, com o mundo da physis, o qual poderia, inclusive, ingressar na esfera do poder humano, sob a forma de propriedade". 29

${ }^{28}$ MENEZES LEITÃO, Cessão de créditos, p.131.

${ }^{29}$ GEDIEL, J. A. P. Tecnociência, dissociação e patrimonialização jurídica do corpo humano. In: FACHIN, L. E. (Coord.). Repensando fundamentos do Direito Civil Basileio contemporâneo. 2. ${ }^{a}$ tiragem. Rio de Janeiro: Renovar, 2000, p.61. Sobre este momento histórico, esclarece Adriana Espíndola Corrêa: "No nominalismo, o domínio que a pessoa exerce sobre si e sobre as coisas do mundo, ao contrário do pensamento tomista, não tem sua origem em uma ordem racional divina, mas na voluntas. Para Guilherme D’Occam, a natureza divina age livremente, com base na voluntas divina, independentemente da razão. O homem, sendo 
Nestas circunstâncias, faltava apenas relativizar a eficácia multicentenária da tradio na transmissão da propriedade para se alcançar a livre disposição deste elemento patrimonial.

Segundo Menezes Leitão, o salto foi dado por Pufendorf:

A doutrina de GROTIUS vem a ser seguida por Pufendorf (1632-1694) para quem a propriedade, consistindo na atribuição de um bem a outra pessoa com exclusão de todas as outras, pode ter por objecto não apenas as coisas corpóreas, mas antes qualquer bem que por si ou justamente com outro possa ser de utilidade para o ser humano. Essencial é apenas que o bem possa ser colocado na esfera de uma pessoa e subtraído à propriedade e conseqüente esfera de vontade de outrem (...).

Assim, PUFENDORF refere-se no capítulo relativo à transmissão da propriedade em termos idênticos à transmissão de coisas e de direitos, sustentando igualmente que, ao contrário do que sucedia no Direito Civil, no jusnaturalismo a entrega material da coisa (tradição) não é necessária à transmissão da propriedade, uma vez que esta seria uma qualitas moralis, uma pura categoria jurídica, que deve ser separada do domínio fáctico sobre o objecto. A posse seria assim em relação à propriedade apenas um complemento, uma pura execução empírica de uma qualitas moralis já existente, a propriedade. Mas, dado que a propriedade como qualitas moralis não poderia depender de circunstâncias físicas, produzindo efeitos de direito erga omnes, apenas o contrato, sendo também uma qualitas moralis, poderia operar a sua

imagem e semelhança de Deus, reproduz a voluntas divina na sua vontade e exerce no mundo sua potestas absoluta. Esses poderes e a liberdade de agir decorrem do dominium que a pessoa tem sobre si e sobre as coisas do mundo, do que se extrai uma vinculação entre a liberdade e a relação de dominium entre a persona e a res" (CORRÊA, A. E. Consentimento do paciente e dever de informar do médico: os limites da autonomia corporal. Dissertação de Mestrado orientada pelo Prof. Dr. José Antônio Peres Gediel, 2002, p.41-42). transmissão, sendo dispensável a tradição, salvo para quem integre a posse no conceito de propriedade. PUFENDORF chega assim à conclusão de que a transmissão da propriedade tanto abrange coisas como direitos (translatio iurium atque rerum), admitindo assim uma sucessão singular nos créditos, na medida em que estes, como objecto de propriedade, poderiam ser transmitidos por contrato. ${ }^{30}$

Estava lançada a base para a fixação da cessão de crédito na etapa da primeira codificação. Pelo menos dois aspectos no pensamento de Pufendorf merecem atenção especial.

Em primeiro lugar, sobressai o redimensionamento da relação entre posse e propriedade e a importância dessa nova construção para uma mitigação da importância da tradição para a transmissão de riquezas. Encontra-se neste ponto a justificação filosófica para a posterior construção conceitual no direito francês de que o contrato, em linha de princípio, por si só é apto a transferir a propriedade.

Ora, a propriedade como qualitas moralis independe da relação fática com a coisa. Esta concepção, por sua vez, acaba sendo projetada na concepção subjetivista da posse como pressuposto indispensável para a eficácia real do contrato em ordenamentos jurídicos como o francês, o italiano, o português, dentre outros.

Verifica-se também, neste momento histórico, uma alteração de perspectiva sobre o fenômeno obrigacional, que deixa de ser preso aos ossos da pessoa para ser expressado mediante um componente patrimonial. Deixa-se o ser para resolver o problema no ter,

30 MENEZES LEITÃO, Cessão de créditos, p. $132-134$ 
numa questão meramente de titularidade, disponibilidade e responsabilidade patrimonial. O crédito é absorvido pelo discurso abstrato e generalizante da propriedade, conforme reflexão crítica de Erolths Cortiano Jr., apontando para uma potencialização extrema das possibilidades de circulação. Neste sentido, o crédito torna-se uma mercadoria. ${ }^{31}$

Esta transposição conceitual fica clara em Collin \& Capitant que definem o crédito como um valor, tornando a pessoalidade do credor e do devedor dispensável na relação jurídica. ${ }^{32}$

$\mathrm{Na}$ era 'segunda codificação', mormente com o Código Civil alemão, adota-se uma solução diversa. O direito alemão é marcado

31 "Na abstração do modelo proprietário, o objeto do direito de propriedade também não se concretiza. Ou, por outras palavras, o sistema conceitual não permite que a noema faça referência e especificação a determinado e conceto bem. $\mathrm{O}$ modelo proprietário deve ser universal e atemporal; deve permitir que a apopriação de todo e qualquer bem se subsuma ao preceito fundamentador do direito de propriedade. A abstração do objeto da propriedade é imprescindível em um sistema baseado na lógica do mercado, onde tudo tem de ser passível de entrar em circulação. Todas as coisas devem reduzir-se então a um mínimo comum, que é a mercadoria. Onde importa o valor de troca e não o valor de uso, tudo se equivale. Para fazer tudo se equivaler, a norma abre mão de conceituar a propriedade a partir da coisa apropriada" (CORTIANO JR, E. O discurso jurídico da propriedade e suas rupturas. Rio de Janeiro: Renovar, 2002, p.124).

32 "La personnalité du débiteur et celle du créancier se sont de plus en plus éliminées du rapport de droit. L'obligation, soit au point de vue actif, soit au point de vue passif, n'a plus été considérée que par son résultat, c'est-à-dire comme un élément de l'actif ou du passif du patrimoine, comme une valeur, aussi rationnellement transmissible que les autres valeurs, que les droits réels et, notamment, que la propriété" (COLLIN, A.; CAPITANT, H. Cous élémentaire de Droit Civil Français. avec le concours de M. Julliot de la Morandière. t.II. 8.ed. Paris: Dalloz, 1935, p.355). por uma rígida separação entre os planos obrigacional e real ${ }^{33}$ postulando, por conseqüência, soluções diferentes para a transmissão das coisas e direitos.

Christoph Krampe entende que, substancialmente, neste ponto resplandece a diferença da noção de bem jurídico no ordenamento francês em face do alemão, pois, enquanto para os franceses bem jurídico "ne signifie pas seulement l'objet, mais aussi le droit sur cet objet", o pensamento jurídico alemão "ne connaît pas de propriété d'une créance. Il n'y a propriété qu'envers des choses, et ce qu'est une chose se trouve défini dans le code civil allemand (article 90), comme suit: <Par chose, dans le sens de la loi, on n'entend que les objets corporels $>$ ".34

Esta diferença essencial na teoria dos bens e de sua transmissibilidade no direito francês perante o direito alemão terá reflexos profundos. No que diz respeito ao direito alemão, vigora a estrita separação de planos, de modo que o negócio jurídico de constituição da relação jurídica obrigacional é diverso e incomunicável com o negócio jurídico de transmissão.

Sobre o sistema alemão, falou suscintamente em aula Alcides Tomasetti Jr.:

Na Alemanha, há um procedimento negocial que tem de ser rigorosamente seguido para que ocorra a aquisição inter vivos da propriedade imobiliária pelo registro. Todo este procedimento foi um tanto artificialmente criado por ocasião da elaboração do BGB, cuja artificiosidade foi

${ }^{33}$ Sobre o assunto, no Brasil, cf. COUTO E SILVA, C. V. A obrigação como processo. São Paulo: Bushatsky, 1976

34 KRAMPE, C. Obligation comme bien: Droit français et allemand. In: Archives de philosophie du droit: L'obbligation. Paris: Dalloz, 2000, p.206. 
motivo de polêmica e de tentativas de reforma, vez que o leigo não conseguiria penetrar na complexidade do sistema alemão de transmissão da propriedade imobiliária.

Para o leigo, tanto no Brasil, quanto na Alemanha, "quem compra é dono".

Imaginemos o contrato de compra e venda no campo das obrigações. Sua eficácia típica é a criação da relação jurídica de compra e venda, na qual incumbe ao vendedor transferir a propriedade da coisa (frise-se, não transfere, promete transfeir), contra o dever do comprador de efetuar a prestação do preço. Este é o núcleo do contrato de compra e venda.

Após o contrato obrigacional, os alemães falam em "acordo de transmissão" (Einigung) e não "contrato de direito das coisas". O significado de "Einigung" é "acordo de transmissão".

Seguindo as explicações de Alcides Tomasetti Jr o sistema alemão de transmissão da propriedade e, com ele, a rígida separação entre o plano obrigacional e real poderia ser sinteticamente descrito da seguinte maneira:

Na Alemanha distinguem-se quatro fases para a transmissão da propriedade imobiliária (Auflassung):

O negócio jurídico contratual (Grundgeschäft) é negócio basal e opera apenas no campo do direito das obrigações, cuja sua eficácia predominante, mas não esgotante, está na criação da relação jurídica de compra e venda, gerando para o vendedor o dever em sentido estrito (isto é, um dever comportamental) de transferir a coisa, e para o comprador, o dever em sentido estrito de transferir o numerário. Havendo consentimento sobre a troca da coisa pelo preço, temos o negócio devidamente aperfeiçoado no plano obrigacional.

Acordo de transmissão. (Einigung, que Pontes de Miranda traduz como negócio juri-real). Os alemães, sob a influência de Savigny, perceberam contratos cujos efeitos não se expandiam somente no campo do direito das obrigações mas também no campo do direito das coisas. A Einigung está no campo do direito das coisas, de modo que na Alemanha pode haver compra e venda perfeita, sem que tenha sido acordada a transmissão da coisa vendida; Eintragungsbeweillung (inserção, na tradução literal; do consentimento para o registro): É negócio jurídico unilateral, que opera exclusivamente no campo do direito das coisas e, cujo conteúdo vem dado pelo consentimento para uma nova aquisição constituída mediante o registro. Assim, na Alemanha, pode-se comprar e vender, e não acordar sobre a transmissão; pode-se acordar para comprar e vender, e desde logo vender e transmitir, em momento simultâneo ou posterior, mas sempre pelo intermédio de dois diversos negócios jurídicos de formação bilateral, isto é, o contrato de venda e compra e o acordo de transmissão. Eintragung: Esta palavra desgina o ato de registro, semelhante ao exercício da chamada 'jurisdição voluntária';

A transmissão imobiliária na Alemanha, portanto, envolve três negócios jurídicos de direito privado (os três primeiros) e um ato jurídico de direito público estatal. ${ }^{35}$

A mesma abstratividade que se interpôe entre o Grundgeschäft e a Einigung (negócio jurídico bilateral ou verdadeiro contrato de direito das coisas: Dinglichervertrag), que marcaria a separação entre o plano obrigacional e o plano real seria verificável, em direito alemão, na cessão de crédito, pela diferença funcional (e abstratividade) entre o negócio jurídico de base - que é causal e propicia o fundamento da disposição patrimonial efetuada mediante o negócio transmissivo subseqüente ou contemporâneo - e o negócio de transmissão do crédito.

Esta duplicidade de negócios, em direito alemão, encontra, dentre outros autores, esta explicação de Karl Larenz:

35 TOMASETTI JR., A. Fundamentos do direito dos contratos. São Paulo, 1999, 130p. (Anotações brevemente revistas pelo docente no decurso de disciplina ministrada em nível de pós-graduação na Faculdade de Direito da Universidade de São Paulo). 
Los denominados negocios dispositivos de créditos tienem carácter abstracto según el sistema del BGB, es decir, su validez en derecho es independiente de su 'causa juridica'. Esta última radica, generalmente, en un negocio obligacional - que precede al acto dispositivo o coincide con él -. Un crédito puede, p.ej., ser cedido por medio de un contrato de compraventa (...) o de donación, y también como medio de cumplimiento de una obligación o en concepto de dación en pago. Por consiguiente, la cesión como negocio dispositivo ha de diferenciarse conceptualmente del negocio básico obligacional y de otras estipulaciones jurídicas causales, aunque ambos, como casi siempre suele ocurrir, coincidan temporalmente y en la conciencia de los interessados. ${ }^{36}$

Esta diferenciação e, sobretudo, a abstratificação do negócio jurídico de transmissão do crédito em face do negócio jurídico básico e causal entre o negócio jurídico de base e o negócio jurídico de transmissão não é reconhecida noutros ordenamentos jurídicos ainda quando a transmissão da propriedade se opera por efeito do contrato. ${ }^{37}$

${ }^{36}$ LARENZ, K. Derecho de obligaciones. t.I. trad. Jaime Santos Briz. Madrid: Editorial Revista de Derecho Privado, 1958, p.447. No mesmo sentido, a explicação de Ennecerus-Lehman: "el contenido de este contrato es la transmisión del derecho de credito. Por tanto, la cesión no ha de confundirse con el contrato por el cual se asume una obligación de ceder, por ejemplo, la venta del crédito. Verdad es que con frecuencia la cesión va unida externamente a este negocio básico (e incluso en la venta del crédito va implícito, por regla general, un contrato tácito de cesión), pero, aunque así sea, la cesión es un contrato abstracto; el convenio sobre el fin no forma parte, en modo alguno, del contrato de cesión" (ENNECCERUSLEHMANN. Derecho de obligaciones. In: ENNECCERUSKIPP-WOLFF. Tratado de derecho civil. trad. Blas Pérez González y José Alguer. t.II. Barcelona: Bosch, 1954, p.382).

37 No direito português, cite-se Menezes Leitão: "No nosso sistema jurídico, o negócio que serve de base à cessão é sempre causal, pelo que a cessão de
Nestas circunstâncias, cabe investigar qual o modelo mais apropriado para compreender a transmissibilidade de créditos e débitos no direito positivo brasileiro.

créditos não constitui entre nós uma forma de transmissão abstracta do crédito" (MENEZES LEITÃO, Cessão de créditos, p.132-134) e Antunes Varela: “(...) fácil é verificar que nenhuma razão existe, em face do sistema jurídico português, para se considerar a cessão de créditos como um negócio abstracto" (VARELA, A. Das obrigações em geral. t.II. 7.ed. Coimbra: Almedina, 1999, p.299). No direito espanhol, lê-se em nota de rodapé na obra de Castán Tobeñas que “(...) como quiera que la traditio debe tener una iusta causa, también la cesión debe basarse en una causa, ya que sin ella sería estéril, y como la cesión puede ser voluntaria y necesaria, según derive de una convención libre de las partes o sea coactivamente impuesta por la ley, su causa será en esta última el precepto legal mismo y en aquélla un negocio jurídico que podrá ser ya un acto a título gratuito (donación), ya un acto a título oneroso (compraventa, permuta), tanto la constitución de una relación obligatoria cuanto la resolución de una relación preexistente (pago)" (TOBEÑAS, Derecho civil español, común y foral, p.243). Em direito italiano, Panuccio adverte que "Vi sono dei casi (e la cessione è fra questi) in cui lo schema negoziale e contrattuale in sé considerato non è sufficiente a determinare gli effetti e deve essere integrato in uno schema più ampio che dia rilievo al sistema di interessi giuridici, cioè alla causa poer cui l’atto si compie. Perché la cessione possa operare giuridicamente la legge richiede espressamente (art. 1260 c.c) un titolo oneroso o gratuito capace di fondare il transferimento. Per ciò la cessione in quanto tale è uno schema incompleto di negozio che va integrato per operare giuridicamente con un titolo oneroso o gratuito" (PANUCCIO, V. Cessione dei crediti. In: Enciclopedia del diritto. t.VI. Milano: Giuffrè, p.850). No mesmo sentido, Umberto Breccia: Per orientarsi tra le divergenti teorie, è opportuno precisare che la cessione resta 'neutra', con riguardo al fondamento giustificativo, soltanto in quanto effetto legale, ma il singolo accordo rivolto alla cessione, una volta stipulato, è valido purchè abbia una 'causa', per qunto quest'ultima possa assumere caratteri diversi in relazione al contenuto della singola operazione contrattuale" (BRECCIA, U. Le obbligazioni. Milano: Giuffrè, 1991, p.779). 


\section{A CESSÃo de CRÉditos No DIREITO BRASILEIRO}

Lacerda de Almeida, tomando por base o direito civil brasileiro anterior à nossa primeira codificação, escreveu: "o pensamento moderno no intuito da mobilização das riquezas, tende a materializar, a corporificar os direitos e obrigações equiparando-os no modo de transferência às cousas mobiliarias".38

Com efeito, no direito brasileiro, desde o Código Civil de 1916, a cessão de crédito é expressamente prevista e, mesmo antes dele, reconhecida pela doutrina e pela jurisprudência. ${ }^{39}$

A doutrina brasileira, com raras porém honrosas exceções, pouco problematizou a cessão de crédito, chegando, quando muito, a afirmar que se trataria, simplesmente, de mais um tipo contratual. ${ }^{40}$

J.M. Carvalho de Mendonça intuiu a impossibilidade de limitar a cessão de crédito a um contrato típico, ao escrever que: “A cessão pode ter por causa qualquer dos meios de transmitir a propriedade; na frase de um

38 LACERDA DE ALMEIDA, F. P. Obrigações. Rio de Janeiro: Ribeiro dos Santos, 1897, p.452.

39 Clóvis Bevilaqua, ao tratar do art. 1.065 do Código Civil de 1916 diz sobre o direito anterior à codificação: "Semelhante a norma, ainda que não devidamente expresso o preceito" (BEVILAQUA, C. Código Civil dos Estados Unidos do Brasil. 10.ed. v.IV. Rio de Janeiro: Francisco Alves, 1955, p.181).

40 Sobre a cessão de créditos como contrato, posiciona-se Silvio de Salvo Venosa: "a natureza contratual do negócio é patente. É um contrato simplesmente consensual, mas por vezes a necessidade obrigará o escrito particular ou a forma pública" (VENOSA, S. S. Direito Civil: teoria geral das obrigações e teoria geral dos contratos. v.II. 3.ed. São Paulo: Atlas, 2002, p.334). jurisconsulto, ela simpatiza com todos os meios de transmissão da propriedade". ${ }^{41}$ Carvalho Santos, do mesmo modo, notou bem que "A cessão dos créditos é, pela sua índole, um instituto que serve para fins diversos". 42

Antes destes autores, Lacerda de Almeida expressara o entendimento de que no fenômeno da cessão de crédito seria possível identificar dois atos distintos: (a) a transferência do crédito (cessão propriamente dita) e (b) o contrato que lhe dá causa:

Cessão é a transferência que o credor faz a terceiro de seu direito contra o devedor. Nada mais é além disso. Mas esta transferência, como a tradição, nada significa, é um acto vasio: nunquam nuda traditio trasnfert dominium sed ita si aliqua causa precedat per quam dominium transferatur.

(...) como a tradição a cessão de creditos suppõe um contracto que a explique e esse contracto é, em regra, o de compra e venda. ${ }^{43}$

A explicação rigorosa dessa duplicação de negócios (negócio jurídico de base e negócio jurídico de transmissão) foi apresentada, em direito brasileiro, originalmente por Pontes de Miranda:

A cessão de crédito é negócio jurídico bilateral de transmissão de crédito entre o credor e outrem. À base dêle pode haver negócio jurídico, porém a cessão de crédito independe dêle, ou da sua existência. A manifestação de

${ }^{41}$ CARVAlHO DE MENDONÇA, M. I. Doutrina e prática das obrigações. 4.ed. aumentada e atualizada por José de Aguiar Dias. Rio de Janeiro: Forense, 1956, p.97.

${ }^{42}$ CARvalho SAntos, J. M. Código civil brasileiro interpretado. 3.ed. v.XIV. Rio de Janeiro: Freitas Bastos, 1945, p.320.

43 LARCEDA DE ALMEIDA, Dos effeitos das obrigações, p.364-365. 
vontade é elemento de acordo de transmissão, e esse acordo semelhante ao acordo de transmissão da propriedade imobiliária ou mobiliária, opera a transmissão sem precisar de qualquer outro elemento (e.g., na transferência da propriedade imobiliária, o registro; na transferência da propriedade mobiliária, a tradição, ou outro ato, inclusive registro.). ${ }^{44}$

A percepção da dualidade entre o negócio jurídico que dá base à cessão (que pode ser um negócio jurídico ou outro ato jurídico) e o efeito de transmissão (o negócio jurídico de cessão de crédito propriamente dito) como adimplemento do negócio jurídico basal é absolutamente indispensável para que este instituto possa servir aos fins diversos, outrora simplesmente percebidos por Carvalho Santos, sem mais reflexões.

Daí o equívoco grave e crasso de limitar a cessão de crédito a um mero tipo contratual, sobretudo em um tipo contratual fechado.

A cessão de crédito pode ter por base um contrato oneroso, sendo que, neste caso, efetivamente existe uma proximidade com o contrato de compra e venda.

A base, todavia, pode ser diversa da compra e venda. É possível ceder um crédito por intermédio de um contrato de doação (cujo adimplemento importe na transferência gratuita de crédito, art. 295, in fine, CC 2002). Do mesmo modo, a cessáo de crédito pode ter por base um negócio jurídico de adimplemento, como a dação em pagamento (art.358, CC 2002), ou um negócio jurídico unilateral como a promessa de recompensa (art. 854, CC 2002); um contrato de cessão fiduciária de créditos em garantia (como,

${ }^{44}$ PONTES DE MIRANDA, Tratado de Direito Privado t.XXIII, p.268.

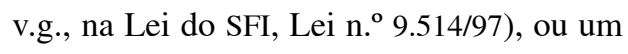
contrato de cessão de um conjunto de créditos futuros, internacionalmente conhecido como contrato de factoring.

Para que a cessão de crédito possa ser realizada enquanto adimplemento de tão diferentes negócios de base é que o legislador enunciou um tipo geral, sem todavia fixar uma causa típica correspectiva. Lê-se no art. 286 do CC 2002, pura e simplesmente, que " $O$ credor pode ceder o seu crédito, se a isso não se opuser a natureza da obrigação, a lei, ou a convenção com o devedor", sem qualquer remissão ao negócio de base que tem de dar causa à transmissão.

No âmbito do direito positivo português, Antunes Varela expõe um esclarecimento que se aplica integralmente ao direito brasileiro: "A cessão tem, por conseguinte, a sua causa, variável de caso para caso, que o artigo 577 intencionalmente omite ao definir a figura, por querer introduzir na noção legal apenas as notas comuns a todas as espécies geradoras do fenómeno da transmissão de crédito". ${ }^{45}$

Cabe investigar a relação que se estabelece entre o negócio jurídico de base e o negócio jurídico de cessão de créditos, em sentido próprio e estrito, perquirindo a abstratividade ou causalidade dessa relação.

\section{ABSTRATIVIDADE E CAUSALIDADE NA CESSÃO DE CRÉDITO}

O debate a respeito da abstratividade ou da causalidade no negócio de cessão de crédito é enfrentado pela quase totalidade da doutrina estrangeira pesquisada a respeito.

\footnotetext{
45 VARELA, Das obrigações em geral, p.299.
} 
Em perspectiva interna, os dados são alarmantes. Poucos autores brasileiros chegam sequer a mencionar o problema, muito provavelmente desatentos por causa da restrição da cessão de créditos a um mero contrato obrigacional ao lado dos demais.

O problema coloca-se nos seguintes termos. No tópico precedente fixou-se o entendimento de que a cessão de crédito, entendida como negócio jurídico de transmissão, tem causa, subjacente ou sobrejacente, variável. Daí Pontes de Miranda referir-se a ela como um acordo de transferência. ${ }^{46}$

Cabe responder se entre o negócio jurídico basal (compra e venda, doação, dação em pagamento, factoring, por exemplo) e a cessão de crédito, como acordo de transferência, há causalidade ou verdadeira abstração causal.

Antunes Varelas destrinça o problema nos seguintes termos:

Diz-se abstracto o negócio cuja validade não é prejudicada pelas faltas ou defeitos inerentes à relação jurídica fundamental que lhe serve de base. Na fixação do seu regime jurídico abstrai-se da causa negotti.

A emissão e o endosso da letra de câmbio (ou dos títulos à ordem, no geral) constituem negócios abstractos, no domínio das chamadas relações mediatas, porque nem o aceitante, nem o endossado, podem opor ao portador (mediato) do título os vícios inerentes ao contrato (relação substancial) que serviu de base ao aceite ou ao endosso. Certos negócios de transmissão de direitos reais são considerados no direito germânico como negócios abstractos, porque

46 "O acordo de transferência do crédito tem completo o seu suporte fáctico com as manifestações de vontade do credor e do terceiro. A notificação é apenas para a eficácia no que toca ao devedor, que se supôe não conhecer o que se passou a respeito da sua dívida" (PONTES DE MIRANDA, Tratado de Direito Privado t.XXIII, p.268). os vícios ligados à relação fundamental (compra, doação, troca, constituição de sociedade, etc.) podem obrigar o adquirente a restituir, nas relações entre as partes, mas não dão lugar ao efeito real próprio da nulidade ou da anulação. ${ }^{47}$

Ao se falar em abstratividade da cessão de créditos, portanto, há que se fixar, em primeiro lugar, em que sentido se utiliza a expressão: se ‘abstrato' por causas variáveis (insuscetível de ser limitado a uma causa eficente) ou 'abstrato' no sentido de descolado quanto a sua existência, validade e eficácia em face do negócio que lhe é "subjacente, sobrejacente, ou justajacente" segundo a terminologia de Pontes de Miranda.

A questão aqui proposta diz respeito ao segundo sentido.

Como foi visto, em direito comparado existem basicamente duas correntes: a corrente alemã, que defende a abstratividade da cessão de crédito em relação ao negócio "subjacente, sobrejacente ou justajacente" e as demais correntes européias que sustentam a causalidade entre o negócio de base e o negócio de transmissão.

$\mathrm{Na}$ pequena e seleta parcela da doutrina nacional que enfrentou o assunto encontram-se os dois posicionamentos.

Pontes de Miranda defende a abstratividade da cessão de créditos:

Trata-se de negócio jurídico abstrato, porém não contrato de direito das coisas (juri-real, dinglicher Verträg). É válida e eficaz a cessão, ainda que a causa não exista, seja ilícita, ou não se realize. Se houve cessão, sem causa, e o cessionário se enriqueceu injustificadamente,

\footnotetext{
47 VARELA, Das obrigações em geral, p.299.
} 
pode o cedente pedir a repetição: o crédito volta; mas, enquanto não passa em julgado a sentença, o crédito pertence ao cessionário.

A cessão de crédito é negócio jurídico abstrato. Porque a cessão é abstrata, em si, não pode ser nula por ilicitude de objeto. Se o negócio jurídico subjacente é nulo, cabe a repetição.

(...) O negócio jurídico de cessão é bilateral, abstrato, acôrdo de transmissão, que independe do negócio jurídico subjacente, ou sobrejacente (cessão de crédito para servir de garantia a negócio jurídico de outrem, ou do próprio cedente). $\mathrm{O}$ efeito translativo, a imediata transferência do crédito ao cessionário, é independente do fim que se colimou, cedendose o crédito. Vale, e é eficaz, a transferência, ainda que se venha a decretar a nulidade, ou a anulação ou a ineifcácia do negócio jurídico subjacente, ou sobrejacente. ${ }^{48}$

Outros juristas pátrios defendem uma inafastável relação de causalidade entre o negócio jurídico de base e o acordo de transmissão do crédito, ainda que sem a clareza observada em Pontes de Miranda.

Orlando Gomes, v.g., posiciona-se expressamente pela causalidade, ainda que não ofereça ao leitor explicação sobre o porquê

48 PONTES DE MIRANDA, Tratado de Direito Privado t.XXIII, p.269-270. Caio Mario da Silva Pereira, ainda que não explicitamente, parece adotar a tese da abstratividade mediante remissão ao direito alemão: "Segundo o conceito hodierno, a cessão de crédito é tratada como negócio jurídico abstrato (Larenz, von Tuhr), que se completa independentemente da indagação de sua causa. Pode-se, entre nós, definila como negócio jurídico em virtude do qual o credor transfere a outrem a sua qualidade creditória, com todos os acessórios e garantias, salvo disposição em contrário. Tanto pode ser esta a venda como a doação. Até mesmo a deixa testamentária. Em qualquer caso, é sempre distinta do negócio jurídico que a originou" (SILVA PEREIRA, C. M. Instituições de Direito Civil. v.II. 20.ed. Revista e atualizada por Luiz Roldão de Freitas Gomes. Rio de Janeiro: Forense, 2003, p.363-64). de sua opinião. ${ }^{49}$ Serpa Lopes identifica a duplicidade entre o negócio jurídico de base e o negócio jurídico de transmissão sem explicar, todavia, se há causalidade ou abstratividade entre eles. ${ }^{50}$

Para encontrar uma solução apropriada ao direito brasileiro, mostra-se necessário ir além dos lindes das regras específicas sobre a cessão de crédito. Isto porque a abstratividade ou a causalidade entre o negócio de base e o negócio de transmissão diz respeito ao sistema de transmissão de riquezas como um todo.

Não se verifica no direito privado brasileiro uma rígida separação entre o plano das obrigações e o plano do direito das coisas. Tampouco é justificável uma rígida separação entre o negócio jurídico de base e o negócio jurídico de transmissão de crédito o que logo se verifica pela ponderação genérica dalgumas estruturas insertas no Código Civil.

49 "No direito alemão, a cessão de crédito é contrato abstrato. Não se confunde com o negócio básico, que pode ser, por exemplo, uma venda, ou uma doação. Conseqüentemente, a validade da cessão não está condicionada à desse negócio, visto como lhe não serve de causa. Entre nós é negócio causal" (GOMES, O. Obrigações. 8.ed. Rio de Janeiro: Forense, 1986, p.246). Noutra oportunidade, o autor destacou que "Como se sabe, a cessão de crédito pode ter diversas causas, dentre as quais são mais comuns: a venditionis causa, a donandi causa e a solvendi causa" (GOMES, O. Cessão de crédito: caracterização. In: Novíssimas questões de Direito Civil. São Paulo: Saraiva, 1984, p.88).

50 “(...) a cessão de crédito é um negócio jurídico não criador de obrigações, senão de transmissão. Por essa transmissão o credor originário é substituído pelo adquirente do crédito, enquanto este permanece objetivamente inalterado, como inalterada, subjetivamente, a posição do devedor como tal" (SERPA LOPES, M. M. Curso de Direito Civil. v.II. Rio de Janeiro: Freitas Bastos, 1955, p.519). 
Para tanto, chama-se a atenção para os seguintes argumentos. Ao tratar das regras gerais do cumprimento das obrigações, o Código Civil, no art. 307 enuncia que "só terá eficácia o pagamento que importar transmissão da propriedade quando feito por quem possa alienar o objeto em que ele consistiu".

No mesmo Código, a disciplina da dação em pagamento, segundo o art. 358 , assim estabelece: "Se for título de crédito a coisa dada em pagamento, a transferência importará em cessão". O artigo seguinte determina: "Se o credor for evicto da coisa recebida em pagamento, restabelecer-se-á a obrigação primitiva, ficando sem efeito a quitação dada, ressalvados os direitos de terceiros".

Ao tratar do pagamento indevido, por sua vez, o art. 880 prescreve "fica isento de restituir pagamento indevido aquele que, recebendo-o como parte de dívida verdadeira, inutilizou o título, deixou prescrever a pretensão ou abriu mão das garantias que asseguravam seu direito; mas aquele que pagou dispõe de ação regressiva contra o verdadeiro devedor e seu fiador".

Ainda que não exista regra específica sobre a abstratificação ou a causalidade da transmissão de crédito em relação ao negócio que lhe dá base e, mesmo considerando que as regras citadas mencionam coisas e não créditos, pode-se perceber que, em geral, os negócios jurídicos transmissivos são causais no direito brasileiro. Esta é uma firme tendência do sistema. ${ }^{51}$

51 Cite-se, neste sentido, reflexão análoga feita no direito italiano: "Era principio tradizionale che la cessione dovesse avere una iusta causa, e che pertanto fosse nula una cessio facta sine causa, o ex
Propugnar pela abstratividade da cessão de créditos conduziria a soluções insustentáveis sob a perspectiva do direito brasileiro. Suponhamos uma doação de créditos do cônjuge adúltero ao seu cúmplice (negócio de base), seguido da efetiva cessão (normalmente feita em momento simultâneo, mas não necessariamente).

Pela tese da abstratividade, a despeito do negócio de doação ser anulável (art. 550 do Código Civil), a transmissão do crédito seria perfeita e inatingível, dada a incomunicabilidade entre as causas.

Do mesmo modo, a dação em pagamento, seguida da transferência do crédito, mesmo quando feita por pessoa absoluta incapaz, propiciaria o pagamento eficaz do cessionário e a inatacabilidade da operação negocial de adimplemento por parte do representante do devedor cedido.

Por fim, o cessionário de créditos de um insolvente poderia receber o pagamento do devedor cedido, sem que esta operação de transferência pudesse ser anulada por fraude contra credores.

Mas por qual razão a abstratividade da cessão de crédito conduz a essas situações?

A cessão de crédito não gera efeitos simplesmente obrigacionais. Trata-se de negócio jurídico dispositivo, justificado pelo exercício eficaz do poder de disposição que,

falsa causa, o generaliter ex omni causa ex qua titulus quo facta fuit annullatur, vel ex simulatione, ex metu, ex defectu insinuationis, ecc. Analogamente alla tradizionale concezione dell'acquisto derivativo della proprietà, legata alla distinzione tra la causa (o titolo), e il modo di acquisto, anche rispetto alla cessione si era affermata fin dal tempo dei glossatori bolognesi, come abbiamo visto, l'esigenza di identificare, oltre alla causa, un atto di cessione" (ASTUTI, Cessione (storia), p.820). 
como regra geral (salvo expressas previsões restritivas), diz respeito à disponibilidade de todos atinge dos os bens integrantes do patrimônio. ${ }^{52}$

Nos negócios jurídicos de disposição, a causalidade mostra-se elemento indispensável para a tutela da segurança do trânsito de riquezas. Ainda que se verifique uma separação entre o negócio jurídico (causal) e o negócio jurídico de adimplemento (abstratificado, de transmissão, de disposição), esta separação há que ser necessariamente relativizada pelo princípio jurídico da causalidade segundo o qual está norteada a transferência de bens (latissimo sensu) no direito privado positivo.

Ainda que a propósito da relação entre o negócio jurídico obrigacional e o negócio jurídico de direito das coisas em matéria de transmissão de bens imóveis, parece oportuna a citação do pensamento de Clóvis do Couto e Silva:

Em sistema de separação relativa, a declaração de vontade que dá conteúdo ao negócio dispositivo pode ser considerada como codeclarada no negócio obrigacional antecedente. É que na vontade de criar obrigações, insere-se naturalmente a vontade de adimplir o prometido. Não fora, assim, o negócio jurídico não teria as condições mínimas de seriedade que o Direito

52 Neste sentido, conforme explicação de Karl Larenz "Por disposición entendemos aquí todo negocio jurídico por el que el titular de un derecho modifica la extensión del mismo o su contenido, o como ocurre en los gravámenes - ambos a la vez. El poder de disposición se ofrece a la doctrina jurídica actual como una parte integrante normal de todo derecho patrimonial que siempre corresponde al titular del derecho, salvo que excepcionalmente esté privado de él por un precepto legal o por disposición judicial, p.ej., en la apertura de un concurso de acreedores" (LARENZ, Derecho de obligaciones, p.445). exige. Daí, porque, quando alguém vende algo, demonstra, também, nesse preciso momento, vontade de adimplir o prometido.

Essa vontade de adimplir é inseparável, no plano psicológico, da vontade de criar obrigações. Faltaria seriedade à vontade criadora do dever, se, ao mesmo tempo, não se desejasse adimplir o prometido. Esta inseparabilidade de vontades, entretanto, só existe, como tal, no plano psicológico. No palno jurídico, bifurca-se essa vontade unitária, a fim de encher negócios jurídicos de dimensões diferentes: o obrigacional e o de adimplemento, ou de direito das coisas. ${ }^{53}$

A causalidade aqui defendida, portanto, apresenta-se como uma decorrência do princípio ético de que os vínculos obrigacionais devem ser dotados de seriedade. Não é necessário recorrer ao voluntarismo - tal como expresso no pensamento de Couto e Silva -, mas aos valores que, objetivamente, iluminam o sistema de disposição.

Na medida em que o negócio jurídico de disposição é voltado diretamente à diminuição do ativo patrimonial de quem dispõe para propiciar o aumento patrimonial de quem recebe, a causalidade deve ser a regra e não a exceção, sobretudo pela razão de que o Código em vigor explicita no sistema uma linha geral de vedação ao enriquecimento sem causa, nos termos do art. 884: "Aquele que, sem justa causa, se enriquecer à custa de outrem, será obrigado a restituir o indevidamente auferido, feita a atualização dos valores monetários".

Procura-se justificar a abstratividade da cessão de crédito, por fim, pela razão de que o devedor não cientificado da cessão, que paga ao cedente em vez de pagar ao

\footnotetext{
${ }^{53}$ COUTO E SILVA, A obrigação como processo,
} p.57. 
cessionário obtém a liberação, nos termos do art. 292 do Código Civil Brasileiro.

$\mathrm{O}$ argumento não convence. $\mathrm{O}$ que se tutela, neste caso, é a boa-fé do devedor cedido, o qual ,segundo as circunstâncias concretas do caso, efetua um pagamento putativo que, em geral, nos termos do art. 309 do Código Civil é eficaz.

Mesmo sem se concordar com um certo exagero ao indicar deveres de conduta especialíssimos ao devedor cedido, a reflexão de Antunes Varela parece muito bem ajustada:

Tem-se dito, no entanto, que são irrelevantes para o devedor (debitor cessus) os vícios do contrato de cessão: se for notificado da cessão, ou dela tiver conhecimento por outra via, e pagar a dívida ao cessionário, o pagamento efectuado pelo debitor cessus conservará a sua validade e eficácia, ainda que a cessão venha posteriormente a ser declarada nula ou anulada. Duas observações cumpre, no entanto, registrar a propósito do tratamento concedido nesse aspecto à situação do devedor.

Em primeiro lugar, não é o simples facto de o crédito ter sido cedido a terceiro que isenta o debitor cessus do dever (de agir de boa fé) que o n. 2 do artigo 762 impõe a ambos os sujeitos da obrigação. E no recto cumprimento desse dever incumbe-lhe averiguar da existência e da validade da cessão, não aceitando como boa qualquer informação irresponsável que acidentalmente chegue ao seu conhecimento ou a afirmação de qualquer pretenso cessionário (do crédito). De contrário, arriscar-se-á a ter mesmo que cumprir segunda vez.

$\mathrm{Se}$, depois de se ter devidamente esclarecido, sobretudo junto do cedente, acerca da existência e da validade da cessão, o devedor cumprir junto do cessionário, o pagamento não perderá, na verdade, a sua validade e eficácia, pelo facto de o contrato de cessão vir mais tarde a ser declarado nulo ou anulado.

Porém, conjugando esta solução com as soluções aplicáveis aos dois aspectos da cessão primeiramente analisados, a conclusão lógica a extrair dessa apreciação global, quanto ao regime do pagamento feito ao cedente antes da notificação ou aceitação da cessão, é que se trata apenas de proteger o pagamento (do devedor de boa fé) ao credor aparente e não de considerar a cessão como um negócio abstracto. ${ }^{54}$

Anote-se, como argumento final pela causalidade, o artigo 182 do Código Civil: “Anulado o negócio jurídico, restituir-se-ão as partes ao estado em que antes dele se achavam, e, não sendo possível restituí-las, serão indenizadas com o equivalente".

Se o negócio jurídico dispositivo (subjacente, sobrejacente ou justajacente) vier a ser anulado ou nulificado a regra é a restituição ao estado em que antes dele se achavam, o que aponta decisivamente para a causalidade da operação.

\section{CONSIDERAÇÕES FINAIS}

Dentre os diversos temas do direito das obrigações, a cessão de crédito conjuga uma série de escolhas, provenientes de políticas legislativas consolidadas, que permitem refletir sobre todo o sistema de direito privado, mormente no que pertine à disposição patrimonial.

Esta via, no entanto, é de mão dupla. A compreensão da cessão de crédito não pode ser minimamente alcançada pela simples reflexão sobre os doze artigos (art. 286-298) que tratam da matéria no Código Civil. É preciso partir do sistema para se compreender esta "parte" do direito civil que, por sua vez, conforme pretendemos demonstrar, encontra-se impregnada por uma determinada e específica lógica de disposição

\footnotetext{
54 VARELA, Das obrigações em geral, p.301-302.
} 
patrimonial. Daí ser altamente injustificável tratar a cessão de créditos, pura e simplesmente, a partir das escolhas encontradas em direito comparado, ignorando as graves diferenças que existem entre os sistemas.

O Código Civil de 2002 trata da cessão de crédito, ao lado da assunção de dívidas, no título II do Livro "Do Direito das Obrigações". Trata-se de escolha acertada que aponta para a diferença entre o negócio jurídico basal e a cessão de créditos como negócio jurídico de adimplemento. ${ }^{55}$ Ademais, o posicionamento sistemático da transmissão de créditos ao lado da matéria tratada no título III, concernente ao adimplemento e extinção das obrigações, promove uma facilitação para compreensão da transmissão das obrigações segundo a metodologia da relação jurídica obrigacional como processo, propugnada, em direito nacional, por Clóvis do Couto e Silva. ${ }^{56}$

55 Segundo Orlando Gomes: “os alemães distinguem, na cessão de crédito, dois aspectos, o fato e o efeito, ensinando que, conforme o ângulo visual do observador, ela se apresenta ou como o antecedente jurídico da transferência do direito do credor ou como a consequiência do ato translativo. $\mathrm{O}$ direito brasileiro considerou a cessão de crédito sob o aspecto dos efeitos, colocando-a coerentemente na parte geral das obrigações e não no título dos contratos (...)" (GOMES, Novíssimas questões de Direito Civil, p.82).

56 Judith Martins-Costa vai mais longe. Para esta autora, a noção de obrigação como processo teria sido reconhecida pelo direito legislado, referindo-se ao Código Civil de 2002, sobretudo no que diz respeito à sua estrutura (MARTINS-COSTA, J. Comentários ao novo código civil. Rio de Janeiro: Forense, 2003, p.1. Com o devido respeito a esse posicionamento, não acreditamos que a ressistematização da mobilidade nas obrigações e das demais matérias seja suficiente para se concluir por uma adoção legislativa da noção de relação jurídica obrigacional como processo, até
Se, na história do direito, pode-se perceber um penoso movimento de impessoalização das relações obrigacionais e reificação do crédito como pressupostos para construção teórica da cessão de crédito (ao que tudo indicada, nascida das práticas comerciais à revelia da conceituação pessoalista da relação obrigacional), contemporaneamente, outro movimento firma-se cada vez mais.

A cessão de créditos, contemporaneamente, passa a representar muito mais do que um sofisticado mecanismo de "transmissão de riquezas". Pode-se identificar muitas vezes, por intermédio da cessão de créditos (bem como da assunção de dívidas e da cessão da posição contratual), autênticas operações de 'criação de riquezas' ampliando consideravelmente a função prático-social deste tradicional instituto. ${ }^{57}$ As operações de factoring representam um exemplo eloqüente.

Tudo isto justifica uma que este tradicional tema do direito das obrigações seja revisitado. O presente estudo, nessa perspectiva, propõe-se servir como provocação para tanto.

mesmo porque o fenômeno obrigacional é inaugurado no Código Civil 2002 a partir das modalidades das obrigações, mantendo sinais de uma perspectiva estrutural estática da relação obrigacional diversa da perspectiva dinâmica proposta por Clóvis do Couto e Silva.

57 Neste sentido, Judith Martins-Costa esclarece que: "No âmbito das relações obrigacionais avultam, como exemplos deste crescente fenômeno, certos contratos que "não servem mais apenas para fazer circular as coisas, mas, tout court, para fazê-las, e em especial para criar produtos financeiros"” (MARTINSCOSTA, Comentários ao novo código civil, p.5). 


\section{REFERÊNCIAS}

ASTUTI, G. Cessione (storia). In: Enciclopedia del diritto. t.VI. Milano: Giuffrè, ano.

BEVILAQUA, C. Código Civil dos Estados Unidos do Brasil. 10.ed. v.IV. Rio de Janeiro: Francisco Alves, 1955.

BRECCIA, U. Le obbligazioni. Milano: Giuffrè, 1991.

CARVALHO DE MENDONÇA, M. I.

Doutrina e prática das obrigações. 4.ed. aumentada e atualizada por José de Aguiar Dias. Rio de Janeiro: Forense, 1956.

CARVALHO SANTOS, J. M. Código civil brasileiro interpretado. 3.ed. v.XIV. Rio de Janeiro: Freitas Bastos, 1945.

COLLIN, A.; CAPITANT, H. Cous élémentaire de Droit Civil Français. avec le concours de M. Julliot de la Morandière. t.II. 8.ed. Paris: Dalloz, 1935.

CORRÊA, A. E. Consentimento do paciente e dever de informar do médico: os limites da autonomia corporal. Dissertação de Mestrado orientada pelo Prof. Dr. José Antônio Peres Gediel, 2002.

CORTIANO JR, E. O discurso jurídico da propriedade e suas rupturas. Rio de Janeiro: Renovar, 2002.

COUTO E SILVA, C. V. A obrigação como processo. São Paulo: Bushatsky, 1976.

ENNECCERUS-LEHMANN. Derecho de obligaciones. In: ENNECCERUS-KIPPWOLFF. Tratado de derecho civil. trad. Blas Pérez González y José Alguer. t.II. Barcelona: Bosch, 1954.

FONSECA, R. M. Modernidade e contrato de trabalho: do sujeito de direito à sujeição jurídica. São Paulo: Editora LTr, 2002.

GAUDEMET, Ée. Théorie genérale des obligations. Paris: Sirey, 1965.

GAUDEMET, J. Naissance d'une notion juridique. Les débuts de l' < obligation> dans le droit de la Rome antique. In: Archives de philosophie du droit: L'Obbligation. Paris: Dalloz, 2000.
GEDIEL, J. A. P. Tecnociência, dissociação e patrimonialização jurídica do corpo humano. In: FACHIN, L. E. (Coord). Repensando fundamentos do Direito Civil Basileiro contemporâneo. $2^{\mathrm{a}}$ tiragem. Rio de Janeiro: Renovar, 2000.

GIORGI, J. Teoría de las obligaciones en el derecho moderno. v.VI. Madrid: Hijos de Reus, 1911.

GOMES, O. Cessão de crédito: caracterização. In: Novíssimas questões de Direito Civil. São Paulo: Saraiva, 1984.

GOMES, O. Obrigações. 8.ed. Rio de Janeiro: Forense, 1986.

JÖRS, P.; KUNKEL, W. Derecho privado romano. Trad. L. Pietro Castro. Barcelona: Labor, 1937.

JOSSERAND, L. Cours de droit civil positif français. v.II. 12.ed. Pais: Sirey, 1933.

KASER, M. Direito privado romano. Lisboa: Calouste Gulbekian, 1999.

KRAMPE, C. Obligation comme bien: Droit français et allemand. In: Archives de philosophie du droit: L'obbligation. Paris: Dalloz, 2000.

LACERDA DE ALMEIDA, F. P. Obrigações. Rio de Janeiro: Ribeiro dos Santos, 1897.

LACERDA DE ALMEIDA, F. P. Dos effeitos das obrigações. Rio de Janeiro: Freitas Bastos, 1934.

LARENZ, K. Derecho de obligaciones. t.I. trad. Jaime Santos Briz. Madrid: Editorial Revista de Derecho Privado, 1958.

LEONARDO, R. X. Direito das obrigações: em busca de elementos caracterizadores para compreensão do livro I da parte especial do Código Civil.In: CANEZIN, C. C. (Org.). Arte jurídica: Biblioteca científica do programa de pós-graduação em Direito Civil e Processo Civil da Universidade Estadual de Londrina. v.I. Curitiba: Juruá, 2005.

MARTINS-COSTA, J. Comentários ao novo código civil. Rio de Janeiro: Forense, 2003. 
MENEZES LEITÃO, L. M. T. Cessão de créditos. Coimbra: Almedina, 2005.

PANUCCIO, V. Cessione dei crediti. In:

Enciclopedia del diritto. t.VI. Milano: Giuffrè.

PONTES DE MIRANDA. Tratado de Direito

Privado. Rio de Janeiro: Borsoi, 1958.

SACCO, R. À la recherche de l'origine de l'obligation. In: Archives de philosophie du droit: L'Obbligation. Paris: Dalloz, 2000.

SERPA LOPES, M. M. Curso de Direito Civil. v.II. Rio de Janeiro: Freitas Bastos, 1955.

SILVA PEREIRA, C. M. Instituições de Direito Civil. v.II. 20.ed. Revista e atualizad apor Luiz Roldão de Freitas Gomes. Rio de Janeiro: Forense, 2003.

STAUT, S. S. Algumas precauções metodológicas para o estudo do direito civil. Arte jurídica: Biblioteca científica do programa de pós-graduação em Direito Civil e Processo Civil da Universidade Estadual de Londrina. v.I. Curitiba: Juruá, 2005.

TOBEÑAS, J. C. Derecho civil español, común y foral. 8.ed. t.III. Madrid: Editorial Reus, 1954.

TOMASETTI JR., A. Fundamentos do direito dos contratos. São Paulo, 1999, 130p.

(Anotações brevemente revistas pelo docente no decurso de disciplina ministrada em nível de pósgraduação na Faculdade de Direito da Universidade de São Paulo).

VARELA, A. Das obrigações em geral. t.II. 7.ed. Coimbra: Almedina, 1999.

VENOSA, S. S. Direito Civil: teoria geral das obrigações e teoria geral dos contratos. v.II. 3.ed. São Paulo: Atlas, 2002 